\title{
Pengaruh Persepsi Keadilan Distributif pada Penilaian Kinerja Terhadap Kinerja Karyawan yang Dimediasi oleh Kepuasan Penilaian Kinerja di PT. Dok dan Perkapalan Surabaya
}

\author{
Fajru Achmi Fauziah \\ Anang Kistyanto* \\ Universitas Negeri Surabaya
}

\begin{abstract}
The purpose of this research is to examine and analyze the effect of distributive justice on performance appraisal to work performance through performance appraisal satisfaction (study on PT. Dok dan Perkapalan Surabaya). This type of research is a causality research studies, with the quantitative approach. This research was using simple random sampling. This research used a sample of 137 respondents was drawn from employees of PT. Dok dan Perkapalan Surabaya in Production Department. The result was based on path analysis method showed that there was a significant direct effect distributive justice on performance appraisal to performance appraisal satisfaction and performance appraisal satisfaction to work performance. But there was not significant direct effect distributive justice of performance appraisal on work performance.
\end{abstract}

Keywords: distributif justice perception, performance appraisal, work performance, and performance appraisal satisfaction

\section{PENDAHULUAN}

Karyawan dianggap sebagai aset strategis bagi organisasi, dan dapat menentukan kelangsungan hidup organisasi (Drucker dalam Esfahani et al., 2014). Hasil atau pencapaian suatu prestasi perusahaan sering kali dikaitkan dengan kinerja karyawannya, maka dari itu manajemen kinerjaperlu dilakukan. Meskipun setiap fungsi manajemen sumber daya manusia berkontribusi terhadap manajemen kinerja, penilaian kinerja memainkan peran signifikan dalam proses manajemen kinerja (Mondy, 2008). Sistem penilaian kinerja organisasi dapat menjadi alat praktis untuk motivasi dan pengembangan karyawan ketika karyawan merasa penilaian kinerja mereka sebagai akurat dan adil (Ilgen et al., dalam Esfahani et al., 2014). Sementara itu, Mondy (2008) berpendapat

*Korespondensi: Anang Kistyanto, Jurusan Manajemen, Fakultas Ekonomi, Universitas Negeri Surabaya, Kampus Ketintang, Jalan Ketintang, Surabaya 60231, Indonesia. E-mail: kistyanto2005@yahoo.co.id 
bahwa tujuan utama dari penilaian kinerja adalah memperbaiki kinerja individu dan organisasi, namun juga ada tujuan lainnya. Tujuan lain tersebut berkaitan erat dengan masalah potensial penilaian kinerja yang seringkali menjadi penyebab ketidakpuasan terhadap penilaian kinerja itu sendiri karena mereka terlalu banyak berharap pada suatu rencana penilaian.

Skarlicki \& Folger dalam Thurston et al. (2012) menemukan bahwa proses penilaian dapat menjadi sumber ketidakpuasan yang ekstrim ketika karyawan percaya sistem ini bias, politik, atau tidak relevan. Persepsi keadilan mengenai berbagai komponen pada sistem penilaian kinerja memiliki implikasi tidak hanya terhadap karyawan, namun juga terhadap organisasi (Latham \& Wexley dalam Getnet et al., 2014). Suksesnya sistem penilaian kinerja bergantung pada persepsi keadilan yang dirasakan karyawan dan reaksi mereka merupakan aspek yang sangat penting untuk proses penilaian (Jawahar dalam Palaiologos et al., 2011). Konsekuensinya, dengan perasaan yang merasa tidak puas, tidak adil pada proses dan ketidakadilan pada penilaian, sebuah sistem penilaian akan mendatangkan kegagalan (Cardy \& Dobbins dalam Palaiologos et al., 2011).

Seorang individu dapat mengubah kualitas dan kuantitas kerjanya untuk memulihkan keadilan ketika ia melihat rasio hasil/input tidak adil. Karyawan menurunkan kinerja mereka untuk mengurangi masukan ketika mereka kurang dibayar, dan meningkatkan kinerja mereka untuk menghasilkan lebih banyak masukan ketika mereka dibayar lebih (Adams et al. dalam Xiyan et al., 2010). Menurut Cropanzano et al. dalam Cowandy (2014), penilaian kinerja dan perlakuan yang adil akan memberikan landasan motivasi bagi karyawan untuk meningkatkan kinerjanya di masa depan.

Pendekatan untuk memahami reaksi dari penilaian kinerja yang disyaratkan adalah melalui pandangan keadilan organisasi (Elicker et al. dalam Dusterhoff et al., 2014). Berdasarkan teori keadilan yang dipaparkan oleh Robbins \& Judge (2008), teori keadilan yang dipikirkan dari sudut keadilan organisasi berfokus pada keadilan distributif, keadilan prosedural, keadilan interaksional. Keadilan distributif berfokus pada keputusan organisasi yang terkait dengan pembayaran upah dan promosi, hal inilah yang selalu menjadi perhatian lebih pada lingkungan karyawan (Cohen-Charash \& Spector, 2001; Cropanzano et al., 2001; Masterson et al., 2000 dalam Xiyan et al., 2010)

Cowandy (2014) melalui penelitiannya menemukan bahwa keadilan distributif tidak berpengaruh terhadap kepuasan penilaian kinerja. Hasil penelitian Warokka et al., (2012) menyatakan bahwa keadilan distributif tidak berpengaruh pada kepuasan penilaian kinerja dan kinerja karyawan. Penelitian Xiyan, Jianqio, \& Degen (2010) secara detail menunjukkan bahwa keadilan distributif memiliki hubungan yang lemah terhadap seluruh dimensi kinerja karyawan yaitu pelaksanaan tugas (task performance) dan dedikasi terhadap pekerjaan (job dedication), namun memiliki hubungan kuat dengan interpersonal facilitation. Sedangkan pada penelitian Thurston \& McNall (2010) ditemukan bahwa persepsi karyawan pada keadilan distributif berpengaruh positif 
terhadap kepuasan karyawan pada penilaian kinerja. Penelitian Palaiologos, Papazekos \& Panayotopoul (2011) ditemukan bahwa tujuan administratif pada penilaian kinerja berhubungan terhadap keadilan distributif.

PT. Dok dan Perkapalan Surabaya merupakan salah satu perusahaan galangan kapal nasional yang bergerak dibidang jasa pembangunan kapal baru dan reparasi. Perusahaan ini menerapkan metode umpan balik 360 derajat dalam melakukan proses penilaian kinerja, dimana atasan dapat menilai bawahan dan sebaliknya bawahan dapat menilai atasan. Peran penilaian kinerja dalam proses pengambilan keputusan di PT. Dok dan Perkapalan Surabaya cukuplah penting. Namun, masih banyak karyawan yang hanya menganggap bahwa penilaian kinerja hanyalah aspek formalitas perusahaan saja. Banyak karyawan juga tidak terlalu antusias dalam proses pelaksanaan penilaian kinerja. Sejalan dengan kondisi tersebut, kinerja karyawan juga fluktuatif dan mengalami penurunan dalam 3 bulan berturut-turut yaitu Maret, April dan Mei 2015. Berdasarkan data statistik Departemen SDM PT. Dok dan Perkapalan Surabaya jumlah karyawan yang terlambat naik rata-rata $22 \%$ tiap bulannya dan jumlah karyawan yang mangkir naik menjadi 2 kali lipat dari jumlah pada bulan sebelumnya.

Ilene Gochman, (Direktur praktik efektifitas organisasi Watson Wyatt) dalam Mondy (2008), menemukan bahwa penggunaan umpan balik 360 derajat sebenarnya berkorelasi negatif dengan hasil-hasil finansial. Mantan CEO GE Jack Welch dalam Mondy (2008), bependapat bahwa sistem umpan balik 360 derajat di perusahaannya telah dimainkan dan karyawan mengatakan hal-hal baik satu sama lain, menghasilkan nilai-nilai yang baik serta pandangan penting lainnya dengan arah yang berlawanan adalah bahwa masukan dari rekan-rekan kerja, yang bisa menjadi pesaing untuk kenaikan bayaran dan promosi, bisa dengan sengaja mendistorsi data dan mensabotase rekan kerja.

Berdasarkan beberapa penelitian yang telah dilakukan sebelumnya dan fenomena pada PT. Dok dan Perkapalan Surabaya, menjadi hal yang menarik bahwa kontribusi keadilan distributif terhadap kinerja karyawan melalui kepuasan penilaian kinerja menjadi sorotan yang perlu diteliti.

\section{TINJAUAN PUSTAKA}

\subsection{Persepsi Keadilan Distributif pada Penilaian Kinerja}

Robbins \& Judge (2008) mengemukakan bahwa keadilan organisasi merupakan persepsi keseluruhan dari apa yang adil di tempat kerja. Karyawan menganggap organisasi adil ketika mereka yakin bahwa hasil-hasil yang mereka terima, cara diterimanya hasil-hasil tersebut, adalah adil. Satu elemen penting dari keadilan organisasi adalah persepsi seorang individu tentang keadilan. Dengan kata lain, menurut keadilan organisasional, keadilan organisasi bisa bersifat subjektif, dan terletak dalam persepsi individu tersebut karena apa yang dianggap tidak adil oleh seseorang mungkin 
dianggap sangat layak oleh individu lain. Menurut Greenberg \& Baron (2008:43) keadilan organisasi merupakan studi persepsi masyarakat terhadap keadilan dalam organisasi. Keadilan organisasi ini terdiri dari keadilan distributif, keadilan prosedural, keadilan interpersonal dan keadilan informasional.

Menurut Robbins \& Judge (2008), keadilan distributif yaitu keadilan tentang jumlah dan pemberian penghargaan di antara individu-individu. Keadilan distributif berfokus terhadap imbalan kerja, penghargaan, promosi, dan sebagainya. Baron \& Greenberg (2008) berpendapat keadilan distributif merupakan bentuk keadilan organisasi yang berfokus pada keyakinan seseorang bahwa mereka telah menerima jumlah wajar untuk dihargai dari hasil yang berhubungan dengan pekerjaan (contoh: kompensasi, pengakuan, promosi, dan sebagainya). Orang-orang yang percaya bahwa mereka telah diperlakukan dengan ketidakadilan distributif pada pekerjaan, mereka cenderung mengalami tingkat stress yang tinggi dan juga merasa tidak puas dengan pekerjaan mereka dan perusahaan dimana mereka bekerja. (perasaan keadilan distributif dapat memiliki dampak besar pada motivasi karyawan untuk melakukan pekerjaan mereka). Colquitt, et al. (2009) memaparkan bahwa keadilan distributif mewakili keadilan yang dirasakan terhadap hasil pengambilan keputusan. Karyawan mengukur keadilan distributif dengan meminta hasil keputusan mengenai gaji, upah, evaluasi kerja, promosi dan tugas kerja, apakah sudah dialokasikan dengan menggunakan norma-norma yang tepat atau tidak.

Keadilan distribusi berakar pada sumber teori keadilan. Pada teori ini terdapat dua tipe susunan perangkat yang dihubungkan dengan keadilan distributif pada penilaian kinerja sebagai hasilnya. Tipe pertama adalah norma keputusan. Penerima keadilan distributif tersusun oleh menyesuaikan diri pada norma sosial yang sudah ada, seperti kewajaran, kepercayaan terhadap keadilan distributif yang diterima adalah adil. Tipe yang kedua tersusun atas tujuan pribadi dari penilaian seperti motivasi, mengajar, menghindari konflik dan menyokong keuntungan pribadi (Adams, 1963; Homas, 1961 dalam Thurston et al., 2010).

Smither dalam Warokka et al. (2012) berpendapat, persepsi keadilan muncul dari anggapan terhadap hasil yang akan diterima. Jika penilaian kinerja dianggap tidak adil, maka manfaat dari penilaian kinerja tersebut dapat mengurangi peningkatan perilaku yang positif dan kinerja (Thomas \& Betz dalam Warokka et al., 2012). Persepsi individu berpengaruh terhadap reaksi afektif mereka, dan reaksi mereka berpengaruh terhadap perilaku mereka. Karyawan memperoleh kepercayaan mengenai kontribusi mereka terhadap organisasi. Kepercayaan ini diperoleh dalam konteks persepsi individu pada kemampuan dan usaha yang telah mereka lakukan, begitupula persepsi pada kemampuan dan usaha yang telah dilakukan karyawan lainnya. Setelah menerima hasil penilaian kinerja, persepsi terhadap penilaian mungkin bertolakbelakang pada kepercayaan mereka terhadap kontribusi yang mereka lakukan. Terpenuhinya ekspektasi mereka terhadap perbedaan tersebut yang akan menyebabkan mereka merasa tidak dinilai dengan adil dan 
menimbulkan ketidakpuasan terhadap penilaian kinerja (Hulin and Organ et al., dalam Thurston et al., 2010).

\subsection{Kepuasan Penilaian Kinerja}

Mondy (2008) berpendapat bahwa penilaian kinerja merupakan sistem formal untuk menilai dan mengevaluasi kinerja tugas individu atau tim. Sedangkan menurut Rao dalam Sinambela (2012) mengemukakan bahwa, penilaian kinerja merupakan sebuah mekanisme untuk memastikan bahwa orang-orang pada tiap tingkatan mengerjakan tugas-tugas menurut cara yang diinginkan oleh atasan mereka. Masalah-masalah sering muncul dalam proses pelaksanaan penilaian kinerja, hal itu dikarenakan implementasi penilaian kinerja yang tidak tepat. Mondy (2008) mengemukakan bahwa permasalahan paling umum yang sering terjadi saat penilaian kinerja disebabkan oleh ketidaknyamanan penilai, ketiadaan obyektivitas, halo/horn error, sikap lunak/sikap keras, central tendency error, bias perilaku terakhir, stereotyping, manipulasi evaluasi, kecemasan karyawan.

Berbagai permasalahan yang mucul karena implementasi penilaian kinerja yang tidak tepat dapat mengakibatkan penurunan kinerja karyawan karena karyawan merasa tidak puas akan penilaian kinerja yang mereka rasakan (Rowland \& Hall, 2011). Menurut Giles \& Mossholder dalam Cowandy (2014), kepuasan terhadap penilaian kinerja dinyatakan sebagai perasaan karyawan terhadap proses sistem penilaian kinerja yang digunakan oleh perusahaan. Hal ini dianggap sebagai faktor penting yang mengukur reaksi karyawan terhadap sistem penilaian dan umpan balik kepuasan.

Kepuasan karyawan terhadap penilaian kinerja berperan dalam menentukan efektivitas penilaian kinerja jangka panjang (Keeping \& Levi dalam Aleassa, 2014). Kepuasan karyawan terhadap penilaian kinerja telah menjadi yang paling sering diukur dan telah terutama dikonseptualisasikan dalam kepuasan. Kepuasan atas praktek penilaian kinerja dapat diukur atau dijelaskan dengan sangat baik dalam hal empat dimensi keadilan seperti distributif, informasi, asosiasi keadilan interpersonal dan prosedural dari hubungan diantara mereka (Getnet, et al., 2014).

Keeping \& Levy dalam Cowandy (2014) menjelaskan bahwa untuk mengukur kepuasan penilaian kinerja, biasanya berfokus salah satu dari tiga komponen dari sistem penilaian, 3 komponen tersebut adalah proses, wawancara dan hasil. Kepuasan penilaian kinerja seringkali dikonseptualisasikan dalam hubungan pada kepuasan dengan penilaian wawancara, sistem penilaian, dan tingkat kinerja (Keeping \& Levi dalam Akhtar et al., 2013). Hulin \& Organ et al., dalam Thurston et al. (2010) berpendapat, komponen yang efektif untuk mengidentifikasi kepuasan karyawan pada penilaian kinerja dapat dibagi kedalam tiga tanggapan dari persepsi tersebut. Adapun tiga tanggapannya adalah kepuasan terhadap penilaian kinerja itu sendiri, kepuasan terhadap sistem penilaian kinerja dan kepuasan terhadap supervisor (penilai). 
Menurut Palailogos et al. (2011), terdapat tiga elemen kepuasan karyawan yang menghubungkan penilaian kinerja yang dijadikan sebagai indikator pengukur kepuasan penilaian kinerja. Yang pertama adalah kepuasan terhadap penilaian. Hal ini didasarkan pada tingginya penilaian yang mendapatkan reaksi positif terhadap penilaian kinerja (Kacmar et al., dalam Palailogos et al., 2011) dan berhubungan dengan kepuasan terhadap proses penilaian kinerja (Jordan et al., dalam Palailogos et al., 2011). Elemen yang kedua adalah kepuasan terhadap penilai. Di sini peraturan menentukan bahwa supervisor memiliki kewajiban untuk menenangkan karyawan jika ada hasil positif dari penilaian kinerja menjadi berbeda, sebagaimana yang mereka utamakan pada penilai dan memberikan umpan balik untuk kinerja mereka. (Milkovinch \& Boudrea dalam Palailogos et al., 2011). Pooyan \& Eberhardt dalam Palailogos et al. (2011) berpendapat bahwa yang terpenting dari penilaian kinerja adalah hubungan karyawan dengan supervisor. Elemen yang ketiga adalah kepuasan terhadap umpan balik dari penilaian kinerja. Umpan balik adalah hal yang penting karena hal ini akan memiliki kekuatan yang berpengaruh pada tanggapan seseorang terhadap penilaiannya (Kluger \& Denisi dalam Palailogos et al., 2011).

\subsection{Kinerja Karyawan}

Kinerja karyawan merupakan hasil kerja secara berkualitas dan kuantitas yang dicapai oleh seseorang karyawan dalam melaksanakan tugasnya sesuai dengan tangung jawab yang diberikan kepadanya (Mangkunegara, 2010). Kinerja dalam menjalankan fungsinya tidak berdiri sendiri, tapi berhubungan dengan kepuasan kerja dan tingkat imbalan yang dipengaruhi oleh keterampilan, kemampuan dan sifat-sifat individu. Danolley et al., dalam Rivai, et al (2005) berpendapat bahwa kinerja individu pada dasarnya dipengaruhi oleh faktor harapan mengenai imbalan, dorongan atau motivasi, kemampuan, kebutuhan dan sifat, persepsi terhadap tugas, imbalan internal dan eksternal, persepsi terhadap imbalan dan kepuasan kerja.

Campbell dalam Xiyan et al. (2010) mengungkapkan bahwa kinerja karyawan terdiri dari, tidak hanya tugas tetapi juga elemen kontekstual yang berhubungan dengan tugas (seperti komponen interpersonal dan motivasi) yang berkontribusi dalam menyusun dua dimensi lain penyusun kinerja. Kinerja kontekstual menjelaskan serangkaian perilaku interpersonal dan kemauan karyawan yang mendukung konteks sosial dan motivasi terhadap kinerja organisasi yang diselesaikan dengan baik. Kinerja kontekstual memiliki dua aspek yaitu interpersonal facilitation dan dedikasi pada pekerjaan (Aryee et al., dalam Xiyan et al., 2010).

Pada penelitian Xiyan et al., 2010, ada tiga elemen yang digunakan untuk mengukur kinerja karyawan. Elemen yang pertama, task performance mengarah kepada perilaku spesifikasi yang menyangkut pekerjaan termasuk tanggungjawab inti pekerjaan yang berhubungan langsung dengan tujuan organisasi (Campbell dalam Xiyan et al., 
2010). Elemen yang kedua, interpersonal facilitation menggambarkan perilaku orientasi interpersonal yang berkontribusi dalam tercapainya tujuan organisasi. Hal ini termasuk semangat kerjasama, memikirkan yang karyawan lain, membangun, dan melakukan perbaikan hubungan (Van Scotter \& Motowidlo dalam Xiyan et al., 2010). Elemen ketiga dedikasi pada pekerjaan (job dedication) menggambarkan perilaku motivasi dan disiplin diri seperti bekerja keras, mengambil inisiatif, dan mengikuti aturan untuk mendukung tujuan organisasi (Van Scotter and Motowidlo dalam Xiyan et al., 2010).

\subsection{Kerangka Konseptual}

Berdasarkan kajian teori dan penelitian terdahulu, maka disusun kerangka konseptual yang menggambarkan pola hubungan antara variabel independen, variabel dependen dan variabel intervening sebagai berikut:

Gambar 1. Kerangka Konseptual

\begin{tabular}{|c|c|c|}
\hline $\begin{array}{l}\text { Persepsi Keadilan } \\
\text { Distributif pada } \\
\text { Penilaian Kinerja } \\
\text { 1. Norma } \\
\text { Keputusan }\end{array}$ & $\begin{array}{l}\text { Kepuasan Penilaian } \\
\text { Kinerja } \\
\text { 1. Kepuasan terhadap } \\
\text { penilaian } \\
\text { 2. Kepuasan terhadap } \\
\text { penilai (supervisor/ }\end{array}$ & $\begin{array}{l}\text { Kinerja Karyawan } \\
\text { 1. Task } \\
\text { performance } \\
\text { 2. Interpersonal } \\
\text { facilitation }\end{array}$ \\
\hline $\begin{array}{l}\text { 2. Tujuan Pribadi } \\
\text { dari Penilaian }\end{array}$ & $\begin{array}{l}\text { atasan) } \\
\text { 3epuasan terhadap } \\
\text { penilaian kinerja }\end{array}$ & $\begin{array}{l}\text { 3. Dedikasi pada } \\
\text { pekerjaan (job } \\
\text { dedication) }\end{array}$ \\
\hline
\end{tabular}

\subsection{Hipotesis Penelitian}

2.5.1 Persepsi Keadilan Distributif pada Penilaian Kinerja dengan Kepuasan Penilaian Kinerja

Tang et al. dalam Salleh et al. (2013) menemukan bahwa unsur-unsur keadilan organisasional yang penting dalam memprediksi kepuasan karyawan dari penilaian kinerja dan komitmen terhadap organisasi. Hasil penelitian ini menyarankan bahwa manajer memiliki kendali atas persepsi karyawan tentang keadilan organisasi dalam rangka memberi efek kepuasan, komitmen dan partisipasi dalam organisasi. Folger et al. dalam Thurston \& McNall (2010), berpendapat bahwa dalam model keadilan, perbedaan-perbedaan yang didapati oleh karyawan pada proses penilaian kinerja 
berdasarkan persepsi mereka, kemudian menjadi alasan atas ketidakpuasan penilaian kinerja. Proses penilaian dapat menjadi sumber ketidakpuasan yang ekstrim ketika karyawan percaya sistem ini bias, politik, atau tidak relevan. Oleh karena itu,secara intuitif, orang akan hanya puas dengan proses penilaian kinerja bila memenuhi kriteria keadilan (Skarlicki \& Folger et al. dalam Warokka et al.,2012).

Warokka et al. (2012) dalam penelitiannya menemukan bahwa keadilan distributif tidak berpengaruh signifikan terhadap kepuasan penilaian kinerja. Cowandy (2014) dalam penelitiannya menemukan bahwa keadilan distributif pada penilaian kinerja tidak berpengaruh terhadap kepuasan penilaian kinerja. Sedangkan Thurston \& McNall (2010) dalam penelitiannya menemukan bahwa persepsi keadilan distributif berpengaruh positif terhadap kepuasan penilaian kinerja. Palaiologos, et al. (2011) dalam penelitiannya juga menemukan bahwa keadilan distributif berpengaruh positif terhadap kepuasan penilaian kinerja. Salleh, et al. (2013) dalam penelitiannya menemukan bahwa ada hubungan yang signifikan antara keadilan pada penilaian kinerja dan kepuasan penilaian kinerja, kepuasan penilaian kinerja terbukti sebagai mediator yang menghubungkan keadilan penilaian kinerja dan komitmen organisasi. Getnet, et al. (2013) dalam penelitiannya menemukan bahwa keadilan organisasi berpengaruh terhadap kepuasan penilaian yang dirasakan. Khim, et al. (2008) dalam penelitiannya menemukan bahwa keadilan penilaian kinerja berpengaruh terhadap kepuasan pada sistem penilaian kinerja.

\section{H1: persepsi keadilan distributif pada penilaian kinerja berpengaruh positif terhadap kepuasan penilaian kinerja.}

\subsubsection{Persepsi Keadilan Distributif pada Penilaian Kinerja dengan Kinerja Karyawan}

Thomas \& Bretz dalam Warokka et al., (2012) mengemukakan bahwa jika penilaian kinerja dianggap tidak adil, maka manfaat dari penilaian kinerja dapat mengurangi dari pada meningkatkan sikap positif karyawan dan kinerja. Pertanyaan dasar penelitian Greenberg \& Baron (2008) dari apa yang membuat penilaian kinerja tampaknya adil adalah salah satu yang pertama untuk menerapkan teori keadilan organisasi untuk evaluasi kinerja. Menurut Cropanzano et al., dalam Cowandy (2014), penilaian kinerja dan perlakuan yang adil akan memberikan landasan motivasi bagi karyawan untuk meningkatkan kinerjanya di masa depan. Penelitian yang dilakukan oleh Salleh, et al., dengan jumlah responden 425 karyawan instansi pemerintah menunjukkan bahwa ada hubungan langsung antara penilaian kinerja dan kepuasan hasil penilaian kinerja.

Warokka, et al. (2012) dalam penelitiannya menemukan bahwa tidak ada pengaruh yang signifikan antara keadilan organisasi secara keseluruhan terhadap kinerja karyawan. Sedangkan Owoyemi \& George (2013) dalam penelitiannya menemukan bahwa ada hubungan yang signifikan antara semua dimensi keadilan pada penilaian 
kinerja terhadap kinerja karyawan. Xiyan et al., (2010) dalam penelitiannya juga menemukan bahwa keadilan distributif memiliki hubungan yang kuat terhadap dimensi kinerja karyawan yaitu interpersonal facilitation.

\section{H2: persepsi keadilan distributif pada penilaian kinerja berpengaruh positif terhadap kinerja karyawan.}

\subsubsection{Kepuasan Penilaian Kinerja dengan Kinerja Karyawan}

Kuvaas dalam Warokka et al. (2012) mengungkapkan bahwa kepuasan karyawan pada penilaian kinerja ditentukan dari kinerja mereka. Menurut Mondy (2008), kesalahan-kesalahan dalam menilai kinerja dan keputusan-keputusan yang didasarkan pada hasil yang tidak valid karena adanya ketidakadilan pada proses penilaian kinerja bisa berdampak serius. Pada puncak pertimbangan-pertimbangan tersebut, para manajer harus memberi perhatian pada konsekuensi-konsekuensi hukum. Sistem penilaian kinerja yang digunakan harus dapat meminimalisir timbulnya masalah-masalah dalam proses penilaian kinerja itu sendiri untuk meminimalisir ketidakpuasan atas sistem penilaian kinerja yang ada. Mengembangkan sistem penilaian kinerja yang efektif telah dan akan menjadi prioritas tinggi bagi manajemen. Penilaian kinerja bukanlah bertujuan untuk sekedar menilai dan tujuan lain yang nyata terlihat memanfaatkan hasil dari penilaian kinerja itu sendiri, namun lebih sebagai alat untuk mempengaruhi kinerja karyawan.

Warokka et al. (2012) dalam penelitiannya menemukan bahwa kepuasan penilaian kinerja tidak berpengaruh signifikan terhadap kinerja karyawan. Sedangkan Rowland \& Hall (2012) dalam penelitiannya menemukan bahwa ketidakpuasan pada penilaian kinerja menimbulkan ketidakpercayaan pada penilaian serta hubungan pembayaran upah dengan prestasi, kondisi tersebut mempengaruhi kinerja karyawan.

\section{H3: kepuasan penilaian kinerja berpengaruh positif terhadap kinerja karyawan.}

2.5.4 Persepsi Keadilan Distributif pada Penilaian Kinerja dengan Kinerja Karyawan melalui Kepuasan Penilaian Kinerja

Cropanzano et al., dalam Cowandy (2014) berpendapat bahwa penilaian kinerja dan perlakuan yang adila kan meningkatkan kepuasan pada hasil penilaian kinerja yang diterima dan memberikan landasan motivasi bagikaryawan untuk meningkatkan kinerjanya di masa depan. Kuvaas dalam Warokka et al. (2012) mengungkapkan bahwa kepuasan karyawan pada penilaian kinerja ditentukan dari kinerja mereka. Ini berarti penilaian kinerja dikelola dengan baik akan menimbulkan kepuasan karyawan tinggi, dansecara berurutan mengangkat performa kerja yang tinggi.

Thomas \& Bretz dalam Warokka et al., (2012) melalui penelitiannya yang mengemukakan bahwa jikapenilaian kinerjadianggap tidak adil, maka dapat mengurangi manfaatdaripenilaian kinerja dan menimbulkan ketidakpuasan pada penilaian sehingga 
sikap positif karyawan dan kinerja menurun.Rowland dan Hall (2012) dalam penelitiannyamenemukan bahwa ketidakadilan yang dirasakan menimbulkan ketidakpuasan pada penilaian kinerja, adanya ketidakpuasan pada penilaian kinerja mempengaruhi kinerja karyawan setelah pelaksanaan penilaian.

\section{H4: persepsi keadilan distributif pada penilaian kinerja berpengaruh positif terhadap kinerja karyawan yang dimediasi oleh kepuasan penilaian kinerja.}

\section{METODE PENELITIAN}

\subsection{Desain Penelitian}

Jenis penelitian ini adalah penelitian kausalitas atau sering disebut penelitian sebab akibat. Hal ini sesuai dengan penjelasan Ferdinand (2006), penelitian kausalitas adalah penelitian yang ingin mencari penjelasan dalam hubungan sebab akibat (causeeffect) antar beberapa konsep atau beberapa variabel atau beberapa strategi yang dikembangkan dalam manajemen. Penelitian ini diarahkan untuk menggambarkan adanya hubungan sebab akibat antara beberapa situasi yang digambarkan dalam variabel, dan atas itu ditariklah sebuah kesimpulan umum. Pedekatan yang digunakan dalam penelitian ini adalah kuantitatif, dimana penelitian ini menggunakan analisis statistik yang menitikberatkan pada pengujian hipotesis. Data yang digunakan dalam penelitian merupakan data terukur (berupa angka-angka) yang akan menghasilkan kesimpulan yang dapat digeneralisasikan.

\subsection{Populasi dan Sampel}

Populasi dari penelitian ini adalah karyawan Departemen Produksi PT Dok dan Perkapalan Surabaya. Karyawan Departemen Produksi berjumlah 180 orang. Penelitian ini menggunakan teknik pengambilan sampel acak sederhana (simple random sampling) dengan ukuran sampel sebesar 137 orang yang diambil dari Tabel Kretjcie (Krejcie dan Morgan dalam Sekaran, 2006) untuk menyederhanakan keputusan ukuran sampel dengan tingkat ketelitian dan keyakinan sebesar $95 \%$ atau alpha 0,05 .

\subsection{Definisi Operasional Variabel}

Persepsi keadilan distributif pada penilaian kinerja merupakan anggapan terhadap hasil penilaian kinerja yang akan diterima karyawan sesuai dengan kepercayaan terhadap kontribusi yang telah dilakukan untuk perusahaan dan berbagai kebijakan perusahaan yang telah mereka terima terkait dengan gaji, promosi, evaluasi kerja, dan tugas kerja. apakah sudah dialokasikan dengan menggunakan norma-norma yang tepat atau tidak (Colquitt, et al., 2009). 
Merujuk pada penelitian Thurston et al., (2010), Adams, 1963; Homas, 1961, mengukur keadilan distributif menggunakan dua indikator, yaitu:

a. Norma keputusan : terdiri dari pemenuhan pada norma sosial yang sudah ada, seperti kewajaran dan kepercayaan terhadap keadilan distributif yang diterima adalah adil

b. Tujuan pribadi dari penilaian : kekuatan tujuan pribadi dari penilaian seperti motivasi, menghindari konflik, mengejar dan menyokong keuntungan pribadi dari penilaian kinerja

Kepuasan terhadap penilaian kinerja dinyatakan sebagai perasaan karyawan terhadap proses sistem penilaian kinerja yang digunakan perusahaan, kepuasan ini berfokus terhadap apa yang dirasakan karyawan terkait dengan sistem penilaian kinerja mereka, dan kepuasan mereka terhadap sistem penilaian kinerja yang digunakan dalam perusahaan (Giles \& Mossholder dalam Cowandy, 2014)

Merujuk pada penelitian Palailogos et al. (2011), ada tiga elemen kepuasan karyawan yang digunakan untuk menghubungkan penilaian kinerja. Adapun tiga elemen tersebut yakni:

a. Kepuasan terhadap hasil penilaian : perasaan puas akan hasil penilaian yang diterima sesuai dengan anggapan kompetensi dan keterampilan diri sendiri

b. Kepuasan terhadap penilai: perasaan puas terhadap apa yang telah dilakukan supervisor atau atasan selaku penilai sesuai dengan prosedur penilaian perusahaan.

c. Kepuasan terhadap umpan balik dari penilaian kinerja : perasaan puas terhadap umpan balik dari penilaian kinerja yang telah dilakukan, hasil dari penilaian kinerja akan mencerminkan umpan balik yang diberikan oleh karyawan.

Kinerja karyawan merupakan hasil kerja secara berkualitas dan kuantitas yang dicapai oleh seseorang karyawan dalam melaksanakan tugasnya sesuai dengan tanggung jawab yang diberikan kepadanya (Mangkunegara, 2010).

Merujuk pada penelitian Xiyan et al.(2010), ada tiga indikator yang digunakan untuk mengukur kinerja karyawan. Adapun ketiga indikator tersebut adalah pelaksanaan tugas (task performance), interpersonal facilitation, dedikasi terhadap pekerjaan (job dedication). Adapun untuk lebih lengkapnya akan dijelaskan dengan pendapat para ahli berikut ini:

a. Task performance: mengarah kepada perilaku spesifik yang menyangkut pekerjaan termasuk tanggungjawab inti pekerjaan yang telah dituangkan dalam job description dan berhubungan langsung dengan tujuan organisasi.

b. Interpersonal facilitation: menggambarkan perilaku orientasi interpersonal yang berkontribusi dalam tercapainya tujuan organisasi. Hal ini termasuk semangat kerjasama individu dalam sebuah team work, memikirkan yang karyawan lain (berempati), membangun hubungan baik antar karyawan serta dengan atasan, dan melakukan perbaikan hubungan jika memiliki masalah dengan karyawan lain. 
c. Dedikasi pada pekerjaan (job dedication): menggambarkan perilaku motivasi dan disiplin diri seperti bekerja keras, mengambil inisiatif, dan mengikuti aturan yang berlaku di perusahaan untuk mendukung tercapainya tujuan perusahaan.

\subsection{Teknik Pengumpulan Data}

Teknik pengumpulan data dalam penelitian ini terbagi menjadi dua bagian yaitu pengumpulan data primer dan data sekunder. Data primer diperoleh dari wawancara dengan karyawan yang terkait dengan sumber informasi variabel penelitian serta sebagian responden, observasi untuk mengetahui kondisi lingkungan kerja terkait dengan variabel penelitian yang ada di perusahaan dan kuesioner sebagai alat pengumpulan data jawaban dari responden. Sedangkan data sekunder diperoleh dari informasi dan data perusahaan yang meliputi; sejarah perusahaan, visi misi perusahaan, identitas perusahaan, job description karyawan, serta perkembangan data kegiatan karyawan.

\subsection{Pengujian Instrumen Penelitian}

Suatu kuesioner dikatakan valid jika pertanyaan pada kuesioner mampu untuk mengungkapkan sesuatu yang akan diukur tersebut. Suatu kuesioner dikatakan reliabel atau handal jika jawaban dari seseorang terhadap pernyataan adalah konsisten atau stabil dari waktu ke waktu (Ghozali, 2011). Uji validitas dilakukan atas dasar masing-masing item pernyataan dengan menggunakan faktor analisis terhadap setiap item pernyataan. Uji reliabilitas dilakukan pada masing-masing variabel.

\subsection{Metode Analisis Data}

Statistik deskriptif merupakan analisis yang digunakan untuk memberikan gambaran atau deskripsi empiris atas data yangdikumpulkan dalam penelitian (Ferdinand, 2006). Dalam penelitian ini statistik deskriptif menggunakan bantuan program SPSS 20.0 for window. Analisis statistik deskriptif yang digunakan ialah distribusi frekuensi dan statistik rata-rata.

Analisis Jalur (Path Analysis) merupakan pengembangan dari analisis regresi, sehingga analisis regresi dapat dikatakan sebagai bentuk khusus dari analisis jalur (regressionis special case of path analysis). Analisis jalur digunakan untuk melukiskan dan menguji model hubungan antar variabel yang berbentuk sebab akibat (bukan bentuk hubungan interaktif/reciprocal). Melalui analisis jalur ini akan ditemukan jalur mana yang paling tepat dan singkat suatu variabel independen menuju variabel dependen yang terakhir (Riduwan dan Kuncoro, 2013). Penelitian ini menggunakan teknik Path Analysis (Analisis Jalur) dengan menggunakan program AMOS (Analysis of Moment Structure) versi 21.Ofor windows. 


\section{TEMUAN DAN PEMBAHASAN}

\subsection{Hasil Uji Instrument Penelitian}

Uji validitas dilakukan atas dasar masing-masing item pernyataan dengan menggunakan faktor analisis terhadap setiap item pernyataan. Suatu pernyataan dikatakan valid jika nilai r-hitung yang merupakan nilai Corrected Item - Total Correlation $>$ r-tabel $>0,30$. Jadi apabila suatu pernyataan memiliki nilai $r$ - hitung dibawah 0.30 maka dikatakan tidak valid (Sugiyono, 2011). Dalam Penelitian ini uji validitas menggunakan program SPSS 20.0 for windows.Berdasarkan uji validitas, total 33 item pernyataan dinyatakan valid karena nilai corrected ite,-total correlation berada di atas $r$ tabel.

Uji reliabilitas konstruk diukur dengan dua kriteria yakni composite reliability dan cronbach alpha dari blok indikator yang mengukur konstruk. Konstruk dinyatakan reliable jika nilai composite reliability maupun cronbach alpha diatas 0,70 (Ghozali, 2011). Dalam Penelitian ini uji reliabilitas menggunakan program SPSS 20.0 for window.Berdasarkan uji reliabilitas, ketiga variabel dinyatakan reliabel dengan hasil sebagai berikut:

\section{Tabel 1. Hasil Uji Reliabilitas Pada Variabel Peneitian}

\begin{tabular}{lcccc}
\hline \multicolumn{1}{c}{ Variabel } & Cronbach Alpha & Cut-off-value & Keterangan \\
\hline Persepsi Keadilan Distributif & pada & 0,75 & 0,70 & Reliabel \\
Penilaian Kinerja & & 0,84 & 0,70 & Reliabel \\
Kepuasan Penilaian Kinerja & 0,89 & 0,70 & Reliabel \\
Kinerja Karyawan & &
\end{tabular}

\subsection{Screening Data}

Pada penelitian ini uji, normalitas menggunakan analisis nilai skewness dan nilai kurtosis pada program SPSS 20.0 for window dengan hasil output sebagai berikut :

Tabel 2. Hasil Uji Normalitas

\begin{tabular}{lcccc}
\hline \multicolumn{1}{c}{ Variabel } & Skewness & $\begin{array}{c}\text { Std. Error } \\
\text { Skewness }\end{array}$ & Kurtosis & $\begin{array}{c}\text { Std. Error } \\
\text { Kurtosis }\end{array}$ \\
\hline $\begin{array}{l}\text { Persepsi Keadilan Distributif } \\
\text { pada Penilaian Kinerja }\end{array}$ & $-0,392$ & 0,207 & 0,312 & 0,411 \\
Kepuasan Penilaian Kinerja & $-0,166$ & 0,207 & $-0,772$ & 0,411 \\
Kinerja Karyawan & $-0,348$ & 0,207 & 0,518 & 0,411 \\
\hline
\end{tabular}

Untuk mengetahui data berdistribusi normal atau tidak dapat dilihat dari nilai ratio skewness dan kurtosis. Data pada masing-masing variabel dikatakan normal apabila nilai ratio skewness dan kurtosis berada antara -2 s/d 2. Nilai ratio skewness variabel dapat dihitung melalui rumus berikut :

Nilai ratio skewness $=\frac{\text { nilai skewness }}{\text { std.error skewness }}$ dan nilai ratio kurtosis $=\frac{\text { nilai kurtosis }}{\text { std.error kurtosis }}$ 
Dengan rumus diatas, maka didapat hasil sebagai berikut :

Tabel 3. Nilai Rasio Skewness dan Rasio Kurtosis

\begin{tabular}{lcc}
\hline \multicolumn{1}{c}{ Variabel } & Rasio Skewness & Rasio Kurtosis \\
\hline Persepsi Keadilan Distributif pada Penilaian Kinerja & $-1,894$ & 0,759 \\
Kepuasan Penilaian Kinerja & $-0,802$ & $-1,878$ \\
Kinerja Karyawan & $-1,681$ & 1,260 \\
\hline
\end{tabular}

Pada penelitian ini, uji outlier menggunakan uji z-score pada program SPSS 20.0 for window. Sampel yang digunakan sebanyak 137 yang artinya masuk dalam golongan sampel besar, maka data dinyatakan outlier apabila skornya $\geq 3$.

Pada Tabel 4 hasil pemeriksaan nilai z-score secara keseluruhan pada masingmasing item menunjukkan tidak ada $\mathrm{z}$-score yang skornya $\geq 3$. Maka dari itu, dapat disimpulkan bahwa secara statistik tidak terdapat pengamatan yang mendeteksi sebagai data outlier. Sehingga data tersebut memenuhi asumsi uji outlier dan layak digunakan dalam estimasi berikutnya.

Tabel 4. Hasil Z-Score

\begin{tabular}{cccc}
\hline No. Item & ZKD & ZKK & ZKP \\
\hline 1 & $-0,60181$ & 0,37178 & $-0,71847$ \\
2 & 0,27297 & 0,51647 & $-0,71847$ \\
3 & 0,49166 & $-0,06231$ & 0,18456 \\
4 & 0,71036 & 0,51647 & 0,86183 \\
5 & $-0,38311$ & $-1,79868$ & $-1,39574$ \\
6 & 0,92905 & 0,22708 & $-0,04120$ \\
7 & 0,49166 & 0,66117 & 0,86183 \\
8 & 0,05427 & $-2,37747$ & $-1,62149$ \\
9 & 0,71036 & 0,80587 & 0,63607 \\
10 & $-1,47659$ & 0,66117 & 0,86183 \\
$\ldots \ldots$ & $\ldots \ldots \ldots$ & $\ldots \ldots \ldots$. & $\ldots \ldots \ldots$ \\
135 & $-0,38311$ & $-0,20701$ & $-0,26695$ \\
136 & 0,27297 & 1,67405 & 1,99061 \\
137 & $-0,60181$ & $-0,93050$ & $-0,94422$ \\
\hline
\end{tabular}

\subsection{Hasil Uji Kelayakan Model}

Setelah data memenuhi kriteria dari asumsi-asumsi yang melandasi pada screening data, kemudian dilakukan analisis jalur. Analisis jalur dalam penelitian ini dilakukan untuk mengetahui pengaruh persepsi keadilan distributif pada Penilaian Kinerja terhadap kinerja karyawan yang dimediasi oleh kepuasan penilaian kinerja pada PT. Dok dan Perkapalan Surabaya. Pengolahan data dilakukan dengan AMOS (Analysis of Moment Structure) versi 21.0 for windows.Setelah asumsi analisis jalur dipenuhi, 
ketepatan suatu model dapat dilihat dari nilai koefisien determinasinya $\left(\mathrm{R}^{2}\right)$. Nilai ini dapat dilihat pada tabel square multiple correlation $\left(\mathrm{R}^{2}\right)$ dari analisis yang dilakukan. Nilai koefisien determinasi dapat dilihat pada tabel berikut ini :

Tabel 5. Hasil Uji Koefisien Determinasi

\begin{tabular}{lc}
\hline \multicolumn{1}{c}{ Variabel } & Estimate \\
\hline Kepuasan Penilaian Kinerja & 0,232 \\
Kinerja Karyawan & 0,413 \\
\hline
\end{tabular}

Berdasarkan Tabel 5 di atas dapat dilihat bahwa nilai koefisien determinasi persepsi keadilan distributif pada penilaian kinerja terhadap kepuasan penilaian kinerja $\left(\mathrm{R}^{2} 1\right)$ yang didapatkan sebesar 0,232. Dan nilai koefisien determinasi persepsi keadilan distributif pada penilaian kinerja terhadap kinerja karyawan $\left(\mathrm{R}^{2} 2\right)$ yang didapatkan sebesar 0,413. Ketepatan model dari data penelitian diukur dari hubungan koefisien determinasi $\left(R^{2}\right)$ di kedua persamaan. Dengan rumus $R^{2}$ model $=1-\left(1-R^{2} 1\right)\left(1-R^{2} 2\right)$, sehingga hasil ketepatan model didapatkan sebagai berikut:

$$
\begin{aligned}
\mathrm{R}^{2} \text { model } & =1-\left(1-\mathrm{R}^{2} 1\right)\left(1-\mathrm{R}^{2} 2\right) \\
& =1-(1-0,232)(1-0,413) \\
& =1-(0,768 \times 0,587) \\
& =1-0,45 \\
& =0,55 \text { atau } 55 \%
\end{aligned}
$$

Hasil perhitungan ketepatan model sebesar 55\% menerangkan bahwa kontribusi model untuk menjelaskan hubungan struktural dari ketiga variabel yang diteliti adalah sebesar $0,55(55 \%)$ dan sisanya $45 \%$ dijelaskan oleh variabel lain yang tidak diteliti dalam penelitian ini. Melihat presentase dari kelayaan model sebesar 55\% tersebut, maka bisa dikatakan bahwa model yang dipakai dalam penelitian ini adalah layak.

\subsection{Hasil Uji Hipotesis}

Berdasarkan Tabel 6 diatas, dapat dilihat bahwa pada hipotesis 1 terdapat nilai CR hitung antara variabel persepsi keadilan distributif pada penilaian kinerja terhadap kepuasan penilaian kinerja lebih besar dari $t$ tabel yakni sebesar 6,406 > 1,656. Sedangkan nilai probabilitas signifikansinya sebesar 0,000 ( $\mathrm{p} \leq 0,05)$. Hal ini menunjukkan bahwa $H 1$ diterima. Artinya, variabel persepsi keadilan distributif pada penilaian kinerja memiliki pengaruh yang signifikan terhadap variabel kepuasan penilaian kinerja.

Berdasarkan Tabel 6 diatas, dapat dilihat bahwa pada hipotesis 2 terdapat nilai CR hitung antara variabel persepsi keadilan distributif pada penilaian kinerjaterhadap kinerja karyawan lebih kecil dari pada $t$ tabel, yaitu sebesar $0,850<1,656$. Nilai probabilitas signifikansinya sebesar 0,395 ( $\mathrm{p} \geq 0,05)$. Hal ini menunjukkan bahwa $\boldsymbol{H} 2$ 
ditolak. Artinya, variabel persepsi keadilan distributif pada penilaian kinerja tidak memiliki pengaruh yang signifikan terhadap variabel kinerja karyawan.

Tabel 6. Hasil Uji Hipotesis

\begin{tabular}{ccccccc}
\hline Hipotesis & Variabel & $\begin{array}{c}\text { Unstandardized } \\
\text { Estimate }\end{array}$ & $\begin{array}{c}\text { Standardized } \\
\text { Estimate }\end{array}$ & S.E. & C.R & P \\
\hline H1 & KP $\leftarrow$ KD & 0,466 & 0,481 & 0,073 & 6,406 & 0,000 \\
H2 & KK $\leftarrow$ KD & 0,058 & 0,064 & 0,068 & 0,850 & 0,395 \\
H3 & $\mathrm{KK} \leftarrow$ KP & 0,570 & 0,609 & 0,070 & 8,125 & 0,000 \\
\hline
\end{tabular}

Berdasarkan Tabel 6 diatas, dapat dilihat bahwa pada hipotesis ketiga terdapat nilai CR hitung antara variabel kepuasan penilaian kinerja terhadap kinerja karyawan adalah sebesar 8,125>1,656 nilai probabilitas signifikansinya sebesar 0,000 ( $\mathrm{p} \leq 0,05)$. Hal ini menunjukkan bahwa $\boldsymbol{H 3}$ diterima. Artinya, variabel kepuasan penilaian kinerja memiliki pengaruh yang signifikan terhadap variabel kinerja karyawan.

\subsection{Hasil Uji Mediasi}

Tabel 7. Standardized Direct Effects, Standardized Indirect Effects, dan Standardized Total Effects

\begin{tabular}{ccccccc}
\hline & \multicolumn{2}{c}{ Standardize Direct Effect } & \multicolumn{2}{c}{ Standardize Indirect Effect } & \multicolumn{2}{c}{ Standardize Total Effect } \\
\hline & $\mathrm{KD}$ & $\mathrm{KP}$ & $\mathrm{KD}$ & $\mathrm{KP}$ & $\mathrm{KD}$ & $\mathrm{KP}$ \\
\hline $\mathrm{KP}$ & 0,481 & 0,000 & 0,000 & 0,000 & 0,481 & 0,000 \\
$\mathrm{KK}$ & 0,064 & 0,609 & 0,293 & 0,000 & 0,357 & 0,609 \\
\hline
\end{tabular}

Pengaruh langsung persepsi keadilan distributif pada penilaian kinerja terhadap variabel kinerja karyawan yaitu sebesar 0,064 lebih kecil dibandingkan pengaruh tidak langsung persepsi keadilan distributif pada penilaian kinerjaterhadap variabel kinerja karyawan yaitu sebesar 0,293. Temuan ini membuktikan bahwa variabel kepuasan penilaian kinerja terbukti sebagai mediasi antara persepsi keadilan distributif pada penilaian kinerjaterhadap variabel kinerja karyawan dengan nilai total sebesar 0,609. Untuk menguji signifikan dari koefisien efek tidak langsung (mediasi) juga dapat menggunakan software yang dikembangkan oleh Sobel (1982) yang lebih dikenal dengan sobel test. Hasil sobel test dalam penelitian ini adalah sebagai berikut : 
Tabel 8. Hasil Sobel Tes

\begin{tabular}{cccc}
\hline & Test Statistic & Std. Error & p-value \\
\hline Sobel Test & 5,02382385 & 0,05287208 & 0,00000051 \\
\hline
\end{tabular}

Berdasarkan Tabel 8 dapat dilihat bahwa nilai probabilitas persepsi keadilan distributif pada penilaian kinerja signifikansinya sebesar $0,00000051(\mathrm{p} \leq 0,05)$. Hal ini menunjukkan bahwa variabel persepsi keadilan distributif pada penilaian kinerjamemiliki pengaruh yang signifikan terhadap kinerja karyawan melalui kepuasan penilaian kinerja. Artinya uji mediasi melalui sobel test diterima.

Hasil uji pengaruh variabel terikat dan variabel bebas dapat menjelaskan hasil uji variabel mediasi. Ada tiga kemungkinan hasil dari uji mediasi, yaitu :
a. Mediasi terbukti secara penuh (fully mediated)
b. Mediasi terbukti secara parsial (partially mediated)
c. Mediasi tidak terbukti.

Hipotesis mediasi pada umumnya diuji dengan dua cara yaitu strategi causal step dan strategi perkalian koefisien. Dalam pengujian dengan causal step Baron dan Kenny (1986) dalam Sarwono (2007) menyatakan empat kondisi yang harus terpenuhi, yaitu :

a. Variabel independen berkorelasi signifikan terhadap variabel mediasi.

b. Variabel independen berkorelasi signifikan terhadap variabel dependen.

c. Variabel mediasi berkorelasi signifikan terhadap variabel dependen ketika variabel independen dimasukkan dalam persamaan regresi.

d. Full/Perfect Mediation terjadi jika pengaruh variabel independen pada variabel dependen secara langsung adalah tidak signifikan, tapi pengaruhnya signifikan ketika melibatkan variabel mediasi. Sedangkan Partial Mediation terjadi jika pengaruh variabel independen pada variabel dependen baik secara langsung maupun tidak langsung adalah signifikan.

Berdasarkan hasil perhitungan pengaruh langsung dan pengaruh tidak langsung serta memperhatikan hasil uji sobel test, maka dapat disimpulkan bahwa pada penelitian ini, mediasi terbukti secara penuh(full/perfect mediation) karena variabel persepsi keadilan distributif pada penilaian kinerjatidak berpengaruh signifikan terhadap variabel kinerja karyawan, namun pengaruhnya berubah signifikan ketika melibatkan variabel mediasi, yaitu kepuasan penilaian kinerja. Hal ini menunjukkan bahwa $H 4$ diterima.Artinya, persepsi keadilan distributif pada penilaian kinerja berpengaruh signifikan positif terhadap kinerja karyawan yang dimediasi oleh kepuasan penilaian kinerja. 


\subsection{Pembahasan}

Persepsi keadilan distributif pada penilaian kinerja berpengaruh signifikan positif terhadap kepuasan penilaian kinerja, secara khusus sebagian besar karyawan di departemen produksi mempercayai bahwa segala keputusan yang dibuat oleh pimpinan terhadap bawahannya bersifat objektif karena karyawan merasa nyaman atas sikap pimpinannya. Sehingga mereka merasa bahwa penilaian yang dilakukan sudah adil dan bukan berupa suka atau tidak suka secara personal. Anggapan karyawan mengenai keadilan keputusan yang dibuat oleh atasannya tersebut menjadikan karyawan merasa puas terhadap hasil penilaian, sikap penilai, dan umpan balik dari penilaian.

Hasil penelitian ini sesuai dengan penelitian Thurston et al. (2010), Palailogos et al. (2011) dan Getnet et al. (2013) yang menemukan bahwa keadilan distributif pada penilaian kinerja berpengaruh positif signifikan terhadap kepuasan kinerja karyawan. Skarlicki dan Folger et al. dalam Warokka et al., (2012) menemukan bahwa proses penilaian dapat menjadi sumber ketidakpuasan yang ekstrim ketika karyawan percaya sistem ini bias, politik, atau tidak relevan. Sehingga secara intuitif, orang akan hanya puas dengan proses penilaian kinerja bila memenuhi kriteria keadilan. Oleh karena itu program penilaian kinerja harus diatur dan di desain dengan baik sehingga semua pihak yang terkait dengan penilaian kinerja dapat merasakan bahwa penilaian kinerja dilakukan dengan transparan, adil dan tepat sasaran.

Persepsi keadilan distributif pada penilaian kinerja berpengaruh signifikan positif terhadap kinerja karyawan, kondisi di lapangan menunjukkan bahwa karyawan departemen produksi bekerja dengan target karena jika kapal tidak diselesaikan sesuai target, maka perusahaan harus membayar pinalti kepada pemesan karena tidak dapat memenuhi pesanan dan menyelesaikan kapal sesuai dengan perjanjian. Persepsi keadilan distributif pada penilaian kinerja yang dirasakan tinggi atau tidak, hal tersebut tidak mempengaruhi kinerja karyawan untuk bekerja memenuhi target.

Mayoritas responden menyatakan bahwa pekerjaan yang saat ini mereka lakukan sudah sesuai dengan minat dan kemampuannya, menikmati pekerjaannya, dan memiliki dedikasi yang tinggi pada pekerjaan sehingga persepsi keadilan distributif pada penilaian kinerja yang dirasakan tinggi atau tidak, hal tersebut tidak mempengaruhi kinerja karyawan secara keseluruhan. Tak hanya itu, terdapat faktor lain yang membuat kinerja karyawan meningkat atau menurunantara lain adalah suasana lingkungan kerja, dukungan dari rekan kerja dan atasan, jam kerja yang sesuai, kesesuaian minat dan keahlian dengan pekerjaan yang dilakukan, serta program-program bagian dari kompensasi non finansial seperti rekreasi dan penghargaan atas prestasi.

Hasil penelitian ini sesuai dengan penelitian Warokka et al. (2012) yang menemukan bahwa tidak ada pengaruh yang signifikan antara keadilan organisasi pada penilaian kinerja terhadap kinerja karyawan. Salah satu dimensi keadilan organisasi dalam penelitian Warokka et al. (2012) merupakan keadilan distributif. Namun, tidak 
sesuai dengan penelitian Owoyemi \& George (2013) dan Xiyan et al. (2010) yang menemukan bahwa keadilan distributif pada penilaian kinerja berpengaruh terhadap kinerja karyawan.

Kepuasan penilaian kinerja berpengaruh signifikan positif terhadap kinerja karyawan. Hal ini karena sebagian besar responden menyatakan manfaat dari penilaian kinerja antara lain untuk mengetahui level kinerjanya sehingga dapat memperbaiki kinerjanya. karyawan juga merasa puas atas sikap pimpinannya yang selalu memberikan informasi untuk memperbaiki kinerja, menegur dan mengingatkan dengan baik saat melakukan kesalahan, mengarahkan dan memberi contoh untuk melakukan perbaikan.Sikap karyawan yang kritis pada permasalahan yang terkait dengan pekerjaanserta mengkomunikasikan dengan atasan saat ada masalah untuk mencari jalan keluarnya, akan memudahkannya untuk melakukan perbaikan kinerja sehingga dapat meningkatkan kinerjanya. Maka dari itu, kepuasan penilaian kinerja yang dirasakan mempengaruhi kinerja karyawan.

Hasil penelitian ini sesuai dengan penelitian Rowland dan Hall (2012), yang menemukan bahwa adanya ketidakpuasan pada penilaian kinerja menimbulkan kecurigaan dan kebigungan tentang manajemen kinerja dan mempengaruhi kinerja karyawan setelah pelaksanaan penilaian.Hasil penelitian ini juga sesuai dengan penelitian yang dilakukan oleh Munir Salleh, et al., menunjukkan bahwa ada hubungan dan pengaruh langsung antara penilaian kinerja dan kepuasan hasil penilaian kinerja.

Cropanzano et et al., dalam Cowandy (2014) berpendapat bahwa penilaian kinerjadan perlakuan yang adilakan meningkatkan kepuasan pada hasil penilaian kinerja yang diterima dan memberikan landasan motivasi bagi karyawan untuk meningkatkan kinerjanya di masa depan. Menurut Mondy (2008), kesalahan-kesalahan dalam menilai kinerja dan keputusan-keputusan yang didasarkan pada hasil yang tidak valid karena adanya ketidakadilan pada proses penilaian kinerja bisa berdampak serius. Pada puncak pertimbangan-pertimbangan tersebut, para manajer harus memberi perhatian pada konsekuensi-konsekuensi hukum. Sistem penilaian kinerja yang digunakan harus dapat meminimalisir timbulnya masalah-masalah dalam proses penilaian kinerja itu sendiri untuk meminimalisir ketidakpuasan atas sistem penilaian kinerja yang ada. Oleh karena itu, tuntutan perusahaan untuk mengembangkan sistem penilaian kinerja yang efektif telah dan akan menjadi prioritas tinggi bagi manajemen karena penilaian kinerja bukanlah bertujuan untuk sekedar menilai dan tujuan lain yang nyata terlihat memanfaatkan hasil dari penilaian kinerja itu sendiri, namun lebih sebagai alat untuk mempengaruhi kinerja karyawan.

Hasil penemuan ini mendukung pendapat Thomas \& Bretz dalam Warokka et al., (2012) yang mengemukakan bahwa jika penilaian kinerja dianggap tidak adil, maka dapat mengurangi manfaat dari penilaian kinerja dan menimbulkan ketidakpuasan pada penilaian sehingga sikap positif karyawan dan kinerja menurun. Hasil penelitian ini sesuai dengan penelitian Rowland dan Hall (2012), yang menemukan bahwa 
ketidakadilan yang dirasakan menimbulkan ketidakpuasan pada penilaian kinerja, adanya ketidakpuasan pada penilaian kinerja mempengaruhi kinerja karyawan setelah pelaksanaan penilaian.

\section{KESIMPULAN}

Berdasarkan pada hasil dan pembahasan yang telah dijelaskan, maka dapat ditarik kesimpulan sebagai bahwa terdapat pengaruh yang signifikan dari persepsi keadilan distributif pada penilaian kinerja terhadap kepuasan penilaian kinerja, persepsi keadilan distributif pada penilaian kinerja tidak berpengaruh signifikanterhadap kinerja karyawan, terdapat pengaruh yang signifikan dari kepuasan penilaian kinerja terhadap kinerja karyawan, persepsi keadilan distributif pada penilaian kinerja berpengaruh signifikan positif terhadap kinerja karyawan melalui mediasi kepuasan penilaian kinerja. Mediasi terbukti secara penuh (full/perfect mediation) karena variabel persepsi keadilan distributif pada penilaian kinerja tidak berpengaruh signifikan terhadap variabel kinerja karyawan, namun pengaruhnya berubah signifikan ketika melibatkan variabel mediasi kepuasan penilaian kinerja.

Hasil penelitian ini didasarkan pada jawaban responden melalui kuesioner dan didukung dengan hasil wawancara karyawan yang terkait sumber informasi variabel penelitian serta sebagian responden. Sehingga, data yang dikumpulkan cukup untuk menggambarkan kondisi yang ada pada objek penelitian.

Keterbatasan dalam penelitian ini adalah populasi dan sampel berasal dari satu departemen atau satu unit kerja yaitu departemen produksi. Budaya organisasi dan etos kerja dalam departemen produksi mungkin berbeda dengan unit kerja lainnya. Maka dari itu, untuk penelitian yang akan datang kami menyerankan agar menerapkan pada departemen yang berbeda untuk objek penelitian. Pada penelitian ini, persepsi keadilan yang diteliti terbatas hanya keadilan distributif saja. Disarankan bagi peneliti selanjutnya agar menambah dimensi persepsi keadilan lainnya diantaranya keadilan prosedural, keadilan interaksional dan keadilan informasional untuk mengetahui pengaruh dimensi keadilan organisasi pada penilaian kinerja.

Pengembangan item-item pernyataan pada variabel persepsi keadilan distributif pada penilaian kinerjadalam penelitian ini masih kurang spesifik, disarankan bagi peneliti selanjutnya agar menambah referensi mengenai indikator variabel persepsi keadilan distributif pada penilaian kinerja, baik dari jurnal-jurnal penelitian ataupun literatur lain untuk memberi pemahaman lebih dan memperkaya rujukan penelitian terkait variabel persepsi keadilan distributif pada penilaian kinerja.

Hasil penelitian ini diharapkan dapat memberikan pemahaman kepada pihak perusahaan agar dapat menjadi pedoman untuk meningkatkan kinerja karyawannya melalui program penilaian kinerja yang telah ada. Berdasarkan jawaban responden pada kuesioner dan hasil wawancara dengan karyawan yang terkait sumber informasi variabel 
penelitian serta sebagian responden, terdapat tiga saran praktis untuk perusahaan. Saran praktis pertama mengacu pada hasil frekuensi jawaban responden melalui kuesioner, didapatkan hasil bahwa persepsi keadilan distributif pada penilaian kinerja memperoleh nilai sedang, sehingga perlu ditingkatkan lagi terutama untuk penggunaan hasil dari penilaian kinerja. Hasil dari penilaian kinerja dalam pengambilan berbagai keputusan hendaknya dikaitkan dengan keputusan-keputusan langsung yang bersifat sebagai peningkatan kesejahteraan karyawan seperti pemberian besarnya gaji, kenaikan gaji, kenaikan golongan, promosi jabatan, dan pemberian reward karyawan berprestasi. Hal tersebut dimaksudkan agar semua elemen pelaku penilaian kinerja mendapatkan manfaat dari penilaian kinerja secara merata, baik untuk perusahaan maupun untuk karyawan.

Saran praktis yang kedua dan ketiga mengacu pada hasil wawancara dengan sebagian responden. Untuk saran praktis kedua yaitu sistem penilaian kinerja hendaknya dilakukan dengan rutin atau berkala dan transparan, sehingga tujuan dan manfaat dari penilaian kinerja itu sendiri dapat tercapai. Adapun saran praktis yang ketiga adalah membuat program khusus pasca penilaian kinerja untuk mengontrol dan merencakan perbaikan kinerja yang dibutuhkan. Program khusus tersebut antara lain seperti pembentukan tim pemantauan kinerja atau studi banding ke perusahaan sejenis yang lebih maju untuk mengembangkan.

\section{DAFTAR PUSTAKA}

Aleassa, H. M. (2014). Performance Appraisal Satisfaction and Counterproductive Behaviours: Direct and Moderating Effects. International Journal of Business Administration, 5(1), 76-89.

Akhtar, T. \& Kahttak, S. (2013). Employee Acceptability of Performance Appraisal: Issue of Fairness and Justice. World Applied Sciences Journal, 24(4), 507-518.

Colquitt, J. A., Jefeery A. L., \& Wesson, M. J. (2009). Organizational Behaviour, Improving Performance and Commitment in the Workplace. New York: McGrawHill Irwin.

Cowandy, J. C. (2014). The Impact of Fair Performance Appraisal to Employee Motivation and Satisfaction towards Performance Appraisal - A Case of PT. XYZ. International Business Management Program, 2(2), 21-28.

Dusterhoff, C. \& Cunningham, J. B. (2014). The Effects of Performance Rating, LeaderMember Exchange, Perceived Utility, and Organizational Justice on Performance Appraisal Satisfaction: Applying a Moral Judgment Perspective. Springer Science Business Media Dordrecht, 119, 265-273.

Esfahani, Nasr, A., Abzari, M. \& Dezianian, S. (2014). Analizyng the Effect of Performance Appraisal Errors on Perceived Organizational Justice. International 
Journal of Academic Research in Accounting, Finance and Management Sciences, 4(1), 36-40.

Ferdinand, A. (2006). Metode Penelitian Manajemen (ed. 2). Semarang: Universitas Diponegoro.

Getnet, B., Jeneba, T., \& Tsegaye, A. (2014). The Effect of Employees' Fairness Perception on Their Satisfaction Towards The Performance Appraisal Practices. International Journal of Management and Commerce Innovations, 2(1), 174-210.

Ghozali, I. (2011). Aplikasi Analisis Multivariate Dengan Program IMB SPSS 19. Semarang: Badan Penerbit Universitas Diponegoro.

Greenberg, J. \& Baron, R. A. (2008). Behaviour in Organization $\left(9^{\text {th }}\right.$ Ed). Upper Saddle River, NJ: Prentice Hall.

Khim, O. K., Ang, S. Y. A., Chong, W. L., \& Hu, W. S. (2008). Teacher Appraisal and It's Outcomes in Singapore Primary School. Journal of Educational Administration, 46(1), 39-54.

Kuncoro, A., \& Riduwan. (2013). Cara Menggunakan dan Memaknai Analisis Jalur (Path Analysis). Bandung: Alfabeta Bandung.

Mangkunegara, A. P. (2010). Evaluasi Kinerja SDM. Bandung: PT Refika Aditama.

Mondy, R. W. (2008). Manajemen Sumber Daya Manusia: Jilid 1 (Ed. 10). Jakarta: Erlangga.

Salleh, M., Amin, A., Muda, S., \& Halim, M. A. S. A. (2013). Fairness Of Performance Appraisal And Organizational Commitment. Asian Social Science, 9(2), 121-128.

Owoyemi, O. \& George, O. (2013). The Use Performance Appraisal System In Enhancing Employees Performance In A Public Sector Agency In Nigeria. International Journal of Academic Research in Business and Social Science, 3(10), 240-249

Palaiologos, A., Papazekos P., \& Panayotopoul, L. (2011). Organizational Justice and Employee Satisfaction in Performance Appraisal. Journal of European Industrial Training, 35(8), 826-840

Robbins, S. P. \& Judge, T. A. (2008). Perilaku Organisasi: Jilid 1 (Ed. 12). Jakarta: Salemba Empat

Rowland, C. A. \& Hall, R. D. (2011). Organizational Justice and Performance: Is Appraisal Fair? EuroMed Journal of Business, 7(3), 280-293

Sarwono, J. (2007). Analisis Jalur untuk Riset Bisnis: Aplikasi dalam Riset Pemasaran, Keuangan, SDM dan Wirausaha (Ed. 2). Yogyakarta : Andi Yogyakarta

Sekaran, U. (2006). Research Methods For Business: Buku 1 (Ed. 4). Jakarta: Salemba Empat 
Sekaran, U. (2006). Research Methods For Business: Buku 2 (Ed. 4). Jakarta: Salemba Empat

Sinambela, L. P. (2012). Kinerja Pegawai, Teori Pengukuran dan Implikasi. Yogyakarta: Graha Ilmu

Sugiyono. (2012). Metode Penelitian Kuantitatif Kualitatif dan R\&D. Bandung: Alfabeta

Sugiyono. (2011). Statistika Untuk Penelitian. Bandung: Alfabeta

Thurston, J., Paul W., \& McNall, L. (2010). Justice Perception Of Performance Appraisal Practices. Journal of Managerial Psychology, 25(3), 201-228

Rivai, V., Basri, A. F. M., Sagala, E. J. \& Murni, S. (2005). Performance Appraisal, Sistem yang tepat untuk menilai kinerja karyawan dan meningkatkan daya saing perusahaan (Ed. 2). Jakarta: PT Raja Grafindo Persada

Warokka, A., Gallato, C. G., Moorthy, T. (2012). Organizational Justice in Performance Appraisal System and Work Performance: Evidence an Emerging Market. Jurnal of Human Resoures Management Research, 2012(2012), 1-18

Xinyan, W., Liao, J., Xia, D., Chang, T. (2010). The Impact of Organizational Justice on Work Performance. International Journal of Manpower, 31(6), 662-677. 